\title{
Proteomic and Genomic Changes in Tau Protein, Which Are Associated with Alzheimer's Disease after Ischemia-Reperfusion Brain Injury
}

\author{
Marzena Ułamek-Kozioł ${ }^{1}$, Stanisław Jerzy Czuczwar ${ }^{2}$, Sławomir Januszewski ${ }^{1}$ and \\ Ryszard Pluta ${ }^{1, * \mathbb{D}}$ \\ 1 Laboratory of Ischemic and Neurodegenerative Brain Research, Mossakowski Medical Research Centre, \\ Polish Academy of Sciences, 02-106 Warsaw, Poland; mulamek@imdik.pan.pl (M.U.-K.); \\ sjanuszewski@imdik.pan.pl (S.J.) \\ 2 Department of Pathophysiology, Medical University of Lublin, 20-090 Lublin, Poland; \\ czuczwarsj@yahoo.com \\ * Correspondence: pluta@imdik.pan.pl; Tel.: +48-22-6086-540/6086-469; Fax.: +48-22-6086-627/668-55-32
}

Received: 29 December 2019; Accepted: 27 January 2020; Published: 30 January 2020

\begin{abstract}
Recent evidence suggests that transient ischemia of the brain with reperfusion in humans and animals is associated with the neuronal accumulation of neurotoxic molecules associated with Alzheimer's disease, such as all parts of the amyloid protein precursor and modified tau protein. Pathological changes in the amyloid protein precursor and tau protein at the protein and gene level due to ischemia may lead to dementia of the Alzheimer's disease type after ischemic brain injury. Some studies have demonstrated increased tau protein immunoreactivity in neuronal cells after brain ischemia-reperfusion injury. Recent research has presented many new tau protein functions, such as neural activity control, iron export, protection of genomic DNA integrity, neurogenesis and long-term depression. This review discusses the potential mechanisms of tau protein in the brain after ischemia, including oxidative stress, apoptosis, autophagy, excitotoxicity, neurological inflammation, endothelium, angiogenesis and mitochondrial dysfunction. In addition, attention was paid to the role of tau protein in damage to the neurovascular unit. Tau protein may be at the intersection of many regulatory mechanisms in the event of major neuropathological changes in ischemic stroke. Data show that brain ischemia activates neuronal changes and death in the hippocampus in a manner dependent on tau protein, thus determining a new and important way to regulate the survival and/or death of post-ischemic neurons. Meanwhile, the association between tau protein and ischemic stroke has not been well discussed. In this review, we aim to update the knowledge about the proteomic and genomic changes in tau protein following ischemia-reperfusion injury and the connection between dysfunctional tau protein and ischemic stroke pathology. Finally we present the positive correlation between tau protein dysfunction and the development of sporadic Alzheimer's disease type of neurodegeneration.
\end{abstract}

Keywords: Brain ischemia; stroke; neuronal death; tau protein; gene expression; dementia; neurodegeneration; human; animals

\section{Introduction}

Ischemic brain injury in the human clinic is the second leading cause of death and the third leading cause of physical disability, and may soon become the main cause of Alzheimer's disease type dementia, and, currently, brain ischemia is proposed to be a risk factor for developing Alzheimer's disease [1-6]. The number of patients who have survived an ischemic stroke with a severe neurological deficit has now reached 33 million, and their number will increase to 77 million by 2030 [3]. Neurological deficits 
after stroke in people have a tendency to improve to a greater or lesser extent. However, for reasons unknown, the cognitive deficit is gradually deteriorating, leading to the development of dementia of the Alzheimer's disease type. At present, human stroke has a heavy burden on global public health and social care as well as clinical practice.

Human and animal brain ischemia causes the production of $\beta$-amyloid peptide accumulation and further impairs the removal of the neurotoxic $\beta$-amyloid peptide from the extra- and intracellular space of the brain [7-14]. Additional evidence suggests that ischemic brain damage in humans and animals may contribute to tau protein dysfunction, especially in neurons $[15,16]$. The dangerous and regular damage of the brain after ischemia-reperfusion is the progressive and delayed dementia of the Alzheimer's disease type [2,4,6,17-25]. Previous brain damage associated with ischemia and reperfusion may further increase the likelihood of developing dementia associated with Alzheimer's disease, increasing the extent of post-ischemic changes, through the proteomic and genomic cascade associated with Alzheimer's disease [26-37]. Based on the above observations, it has been suggested that the history of cerebral ischemia in humans and animals is associated with the subsequent development of sporadic Alzheimer's disease [1,7,12,15-17,26-36,38-46]. In this review, we focus first on identifying the response of the tau protein gene and its product to ischemia-reperfusion brain damage. Secondly, we will present the contribution of tau protein after ischemia to the development of sporadic Alzheimer's disease type of neurodegeneration, focusing on both changes in its structure and the expression of its gene after brain ischemia insult.

\section{Structure, Physiological and Pathological Activity of Tau Protein}

Tau protein was first isolated and named in 1975 for its ability to induce tubule formation, and was mostly segregated into neuronal axons. Tau protein can be also detected in oligodendrocytes. Besides the nervous system, tau protein was also found in many other tissues, such as heart, lung, kidney, and testis, but less abundant. The tau protein is a phospho protein and its action depends on the level of its phosphorylation. The tau protein is naturally unfolded with low secondary structure content. Tau protein is composed of four regions: an $\mathrm{N}$-terminal projection region, a proline-rich domain, a microtubule-binding domain, and a C-terminal region (Figure 1) [47]. Six isoforms of tau protein have been found in human adult brains; they are expressed by alternative splicing around the N-terminal projection region and microtubule-binding domain. Tau protein is mainly expressed in the brain, it has six isoforms produced by alternative mRNA splicing of microtubule-associated tau protein gene which comprises 16 exons on chromosome 17q21.31. The primary physiological function of tau protein is to stabilize microtubule networks within neurons, whereas the hyperphosphorylated condition will significantly reduce its biological activity. The main physiological tau protein function in the cell is regulating microtubule structure and dynamics by binding to microtubules, it has been also proven in cell-free conditions. Furthermore, the dynamic microtubule network provided by tau protein is important to the proper migration of new neurons, and severe reduction of adult neurogenesis was found in tau protein knockout mice [47]. The tau protein's functions are regulated by a complex array of post-translational modifications, such as glycation, phosphorylation, isomerization, acetylation, sumoylation, nitration, O-GlcNAcylation, and truncation-these suggest that tau protein plays opposite roles in physiology and pathology [47]. According to previous observations, the kinds of dysfunctional tau protein are different in diverse brain ischemia models, such as neurofibrillary tangle formation, hyper-phosphorylation, dephosphorylation, and re-phosphorylation (Table 1). The hyper-phosphorylated state is the particularly pathological condition of tau protein in post-ischemic brains. It decreases the affinity of tau protein for the microtubules by disrupting the binding balance [47]. The tau protein contains a large amount of serine and threonine residues, which are potential phosphorylation sites, and the phosphorylation state, which is controlled by the balance of kinase and phosphatase activity, affects the affinity of microtubule binding. As the tau protein is phosphorylated by kinases involved in various transduction signaling pathways, its degree of phosphorylation controls its binding to microtubules, affecting the dynamics of microtubule assembly 
necessary for axon growth and neurite plasticity [48]. Hyperphosphorylated tau protein does not bind or stabilize microtubules, while fully dephosphorylated tau protein binds to microtubules with high affinity. Brain ischemia damages the neuronal cytoskeleton both by promoting its proteolysis and by affecting the activity of kinases and phosphatases [49]. Therefore, the physiological activity of the tau protein preferentially affects the development of microtubules and their stabilization by phosphorylation. Microtubules are involved in maintaining the structure of neurons and creating axonal and dendritic processes, and play an important role in vesicular axonal transport and signal transduction. Modifications of tau protein phosphorylation may alter its circulation between the axon and the cell body and affect susceptibility to proteolysis, affect microtubule stability and may contribute to disrupting axonal transport, but also facilitate neurite plasticity in the regenerative response [48]. Another study showed that the tau protein alone can reduce the transport of the amyloid protein precursor from the body of the neuron to axons and dendrites, leading to the storage of the amyloid protein precursor in the body of the nerve cell [50]. Current research presents numerous new functions of tau protein, such as neural activity control, iron export, protection of genomic DNA integrity, neurogenesis and long-term depression [16].

Tau protein structure

\begin{tabular}{|l|l|l|l|}
\hline N-terminal region & Prolin-rich domain & Microtubule-binding domains & C-terminal region \\
\hline
\end{tabular}

Figure 1. Structure of tau protein: N-terminal region, prolin-rich domain, microtubule-binding domains and C-terminal region. 1-441 number of amino acids.

Table 1. Different patterns of tau protein phosphorylation in post-ischemic brain.

\begin{tabular}{|c|c|c|c|c|c|c|c|}
\hline $\begin{array}{l}\text { Animal or } \\
\text { Human }\end{array}$ & $\begin{array}{l}\text { Kind of } \\
\text { Ischemia }\end{array}$ & $\begin{array}{l}\text { Time of } \\
\text { Ischemia }\end{array}$ & Region of Brain & $\begin{array}{l}\text { Tau Protein } \\
\text { Changes }\end{array}$ & $\begin{array}{c}\text { Tau Protein } \\
\text { Phospho-Site }\end{array}$ & $\begin{array}{l}\text { Effect of Tau Protein } \\
\text { Changes }\end{array}$ & Ref. \\
\hline Human & $\begin{array}{l}\text { Ischemic } \\
\text { stroke }\end{array}$ & Lack & Ischemic cortex & $\begin{array}{c}\text { Neurofibrill-ary } \\
\text { tangle }\end{array}$ & Tau 1 & Final stage of tau changes & [51] \\
\hline Mouse & $\begin{array}{c}\text { Global } \\
\text { ischemia }\end{array}$ & $\begin{array}{l}10,15,18 \\
\text { min. }\end{array}$ & $\begin{array}{l}\text { Hippocampus, } \\
\text { cortex }\end{array}$ & $\begin{array}{l}\text { Paired helical } \\
\text { filaments }\end{array}$ & Ps396, Ps404 & Neuron death & [52] \\
\hline Rat & Focal ischemia & $1 \mathrm{~h}$. & Ischemic cortex & $\begin{array}{l}\text { Neurofibrill-ary } \\
\text { tangle- like }\end{array}$ & P-396, P-404 & $\begin{array}{c}\text { Progression of ischemic } \\
\text { changes }\end{array}$ & [49] \\
\hline Mouse & Focal ischemia & $90 \mathrm{~min}$ & Ischemic core & $\begin{array}{l}\text { Hyperphos- } \\
\text { phorylation }\end{array}$ & Ser262, Ser356 & $\begin{array}{c}\text { Involve- } \\
\text { ment of asparagine } \\
\text { endopepti- dase }\end{array}$ & [53] \\
\hline Rat & Focal ischemia & $1 \mathrm{~h}$ & Ischemic cortex & $\begin{array}{l}\text { Hyperphos- } \\
\text { phorylation }\end{array}$ & $\begin{array}{l}\text { PT181, pS202, pT205, } \\
\text { pT212, pS214, pT231, } \\
\text { pS262, pS396, pS404, } \\
\text { pS422 }\end{array}$ & $\begin{array}{c}\text { Destabiliza- tion of } \\
\text { neuronal cytoskeletonand } \\
\text { apoptosis }\end{array}$ & [54] \\
\hline Rat & Focal ischemia & $1 \mathrm{~h}$ & Ischemic cortex & $\begin{array}{l}\text { Hyperphos- } \\
\text { phorylation }\end{array}$ & $\begin{array}{l}\text { Phospo-tau protein } \\
\text { 202/205, 214, 396/404, } \\
231 .\end{array}$ & $\begin{array}{l}\text { Progression of ischemic } \\
\text { changes }\end{array}$ & [55] \\
\hline Rat & $\begin{array}{l}\text { Global } \\
\text { ischemia }\end{array}$ & $15 \mathrm{~min}$ & Ischemic cortex & $\begin{array}{l}\text { Hyperphos- } \\
\text { phorylation }\end{array}$ & Ser202, Thr205 & $\begin{array}{l}\text { Oxidative stress, neuron, } \\
\text { astrocyte damage. }\end{array}$ & [56] \\
\hline Rat & Focal ischemia & $90 \mathrm{~min}$ & Ischemic core & $\begin{array}{l}\text { Hyperphos- } \\
\text { phorylation }\end{array}$ & Asp421 & Axonal changes & [57] \\
\hline Gerbil & $\begin{array}{l}\text { Forebrain } \\
\text { ischemia }\end{array}$ & $5 \mathrm{~min}$ & Hippocampus & $\begin{array}{l}\text { Hyperphos- } \\
\text { phorylation }\end{array}$ & Ser199, Ser202 & $\begin{array}{l}\text { Induction MAP kinase, } \\
\text { CDK5, GSK3, neuronal } \\
\text { damage }\end{array}$ & [58] \\
\hline Human & $\begin{array}{l}\text { Ischemic } \\
\text { stroke }\end{array}$ & Lack & Ischemic cortex & $\begin{array}{l}\text { Hyperphos- } \\
\text { phorylation }\end{array}$ & Ser101 & $\begin{array}{l}\text { Microglia tau protein } \\
\text { injury }\end{array}$ & [59] \\
\hline Rat & $\begin{array}{l}\text { Global } \\
\text { ischemia }\end{array}$ & $2,8 \mathrm{~min}$ & $\begin{array}{c}\text { Cortex, } \\
\text { hippocampus }\end{array}$ & $\begin{array}{l}\text { Phosphory-lation, } \\
\text { dephospho- rylation }\end{array}$ & $\begin{array}{l}\text { Ser 396, 262, 202, } \\
\text { Thr205 }\end{array}$ & AMPK changes & [60] \\
\hline Mouse & $\begin{array}{l}\text { Focal ischemia } \\
+ \text { hypoxia }\end{array}$ & $40 \mathrm{~min}$ & Ischemic core & $\begin{array}{c}\text { Decrease in } \\
\text { phosphoryla-tion }\end{array}$ & P301L & $\begin{array}{l}\text { Accumula- tion of } \\
\text { glutamate }\end{array}$ & [61] \\
\hline Rat & $\begin{array}{l}\text { Global } \\
\text { ischemia }\end{array}$ & $5,15 \mathrm{~min}$ & $\begin{array}{l}\text { Neocortex, } \\
\text { hippocampus, } \\
\text { striatum }\end{array}$ & Dephospho-rylation & Ps396, Ps404 & $\begin{array}{l}\text { Changes in axonal } \\
\text { transport }\end{array}$ & [48] \\
\hline Dog & $\begin{array}{c}\text { Global } \\
\text { ischemia due } \\
\text { to cardiac } \\
\text { arrest }\end{array}$ & $10 \mathrm{~min}$ & Cortex & $\begin{array}{l}\text { Dephospho- } \\
\text { rylation, rephospho- } \\
\text { rylation }\end{array}$ & Ser262, Ser356 & Neuronal changes & [62] \\
\hline Mouse & Focal ischemia & $90 \mathrm{~min}$ & Ischemic cortex & $\begin{array}{l}\text { Tau protein }-/ \text { - in } \\
\text { mice }\end{array}$ & Lack & Reduce excitotoxici-ty & [63] \\
\hline
\end{tabular}




\subsection{Tau Protein in Post-Ischemic Brain}

Initial tau protein staining was presented in both neural and glial cells in the hippocampus, cortex and thalamus in both experimental and human brain ischemia [59,64-71]. Tau protein was also observed in microglia after focal ischemia of the brain in ischemic penumbra [57,71]. The data presented indicate that some neurons show changes in the tau protein after ischemia-reperfusion brain injury [67], which may be related to the main neuropathological stage of ischemic processes in these cells [69].

\subsection{Tau Protein in the Blood After Brain Ischemia and Ischemic Blood-Brain Barrier}

An increased level of amyloid in the blood after an ischemic episode [72,73] can indirectly affect changes in tau protein in the blood, representing an automated link between the accumulated amyloid and tau protein pathology after ischemic blood-brain barrier failure [74]. In addition, both oxidative stress [75] and neuroinflammation [76] induced by the permeability of the blood-brain barrier may initiate phosphorylation of tau protein and the development of neurofibrillary tangles after brain injury as a result of ischemia-reperfusion (Table 1) $[16,49,51,54,55,77]$. Tau protein accumulated in the blood after a ischemia-reperfusion brain episode [78,79] can cross the ischemic blood-brain barrier and tau protein originating from serum can cause a stronger tau protein pathology in the brain parenchyma [80]. Ischemia-reperfusion brain injury with ischemic insufficiency of the blood-brain barrier [7,81-85] initiates tau protein phosphorylation $[53,54,56,57,77]$, and phosphorylated tau protein may cause damage to the blood-brain barrier, leading to harmful feedback reactions [74]. The permeability of the blood-brain barrier may exacerbate neuropathology through the tau protein from blood in brain damage as a result of ischemia-reperfusion by increasing its level in brain tissue, which suggests that the ischemic-reperfusion episode of the brain may play an important role in the growth of the blood tau protein level [78-80].

\subsection{Dysregulation of the Tau Protein Gene After Brain Ischemia}

A recent report indicated the relationship between hippocampal CA1 region neuron damage and the expression of the tau protein gene after $10 \mathrm{~min}$ experimental global brain ischemia due to cardiac arrest, with recirculation of 2, 7 and 30 days [15]. In the neurons of the CA1 area, the tau protein gene expression increased to a maximum of 3-fold change on the second day after brain ischemia [15]. On the seventh day of reperfusion after the ischemic episode, gene expression ranged from 0.2 to -0.5 -fold change [15]. On the thirtieth day of recirculation after brain ischemia, the expression of the tau protein gene was below the control values [15]. The statistical significance of the changes in the neuronal gene expression of the tau protein after brain ischemia-reperfusion injury in rats was between 2 and 7, and 2 and 30 days of recirculation [15].

In the CA3 region of the hippocampus, the expression of the tau protein gene after ischemic injury with a survival of 2 days was lower than the control values and higher than the control values on days 7-30. On the second day after ischemia, the minimum was a -0.6 -fold change and the maximum was a -0.001 -fold change, with a median -0.2 -fold change [86]. On the seventh day after ischemia, the minimum was a 0.1 -fold change and the maximum was a 0.6 -fold change, with a median 0.2 -fold change [86]. On the thirtieth day after ischemia, the minimum was a 0.03 -fold change and the maximum was a 0.34 -fold change, with a median 0.18-fold change [86]. The changes were statistically significant between 2 and 7 days and between 2 and 30 days after ischemia [86].

Data show that brain ischemia activates neuronal changes and death in the hippocampus in a manner dependent on tau protein, thus determining a new and important way to regulate the survival and/or death of post-ischemic neurons. 


\subsection{Phosphorylation of Tau Protein After Brain Ischemia}

In some studies, after an experimental focal and global ischemia-reperfusion episode of the brain, dephosphorylation of tau protein was demonstrated (Table 1) [48,62,66,67]. After transient complete cerebral ischemia with recirculation due to cardiac arrest, the tau protein was gradually re-phosphorylated (Table 1) [62]. Transient local brain ischemia in rats with recirculation induced a site-specific hyperphosphorylation of the tau protein (Table 1) [54]. During the death of neurons in the CA1 region of the hippocampus after transient cerebral ischemia in the gerbil, hyperphosphorylation of serine 199/202 tau protein was regulated by GSK3, MAP kinase and CDK5 activity (Table 1) [58]. In addition, it was observed that the microglial tau protein is phosphorylated after ischemic brain damage in humans (Table 1) [71]. Current research indicates that after transient focal and global ischemia of the brain with reperfusion, modifications of the hyperphosphorylation of tau protein are similar to those occurring in Alzheimer's disease and predominate in cortical neurons and are accompanied by apoptosis (Figure 2) $[49,55,57,87]$. The above data indicate that, after ischemia-reperfusion brain injury, neural apoptosis is directly related to the hyperphosphorylation of the tau protein. Khan et al. [52] showed an increase in the production of paired helical tau protein filaments after global cerebral ischemia in mice. Wen et al. $[49,55]$ provided evidence that transient brain injury due to ischemia and reperfusion was involved in Alzheimer's disease-like neurofibrillary tangle generation in female rats after local cerebral ischemia (Table 1). The formation of neurofibrillary tangles was observed after focal ischemia-reperfusion injury of the brain on the side of massive cerebral infarction in humans (Table 1) [54]. In addition, the combination of total brain ischemia with hyperhomocysteinemia in rats led to enormous neuronal changes in the hippocampus and cortex caused by hyperphosphorylated tau protein (Table 1) [56]. The above study reported a 695-fold increase in hyperphosphorylated tau protein-positive neurons in the ischemic brain compared to the control [56]. As an endpoint, the tau protein, a fundamental feature of Alzheimer's disease, aggravates brain tissue damage in transient experimental brain ischemia through tau protein excitotoxicity (Figure 2) $[63,88]$ and tau protein-mediated iron export [89].

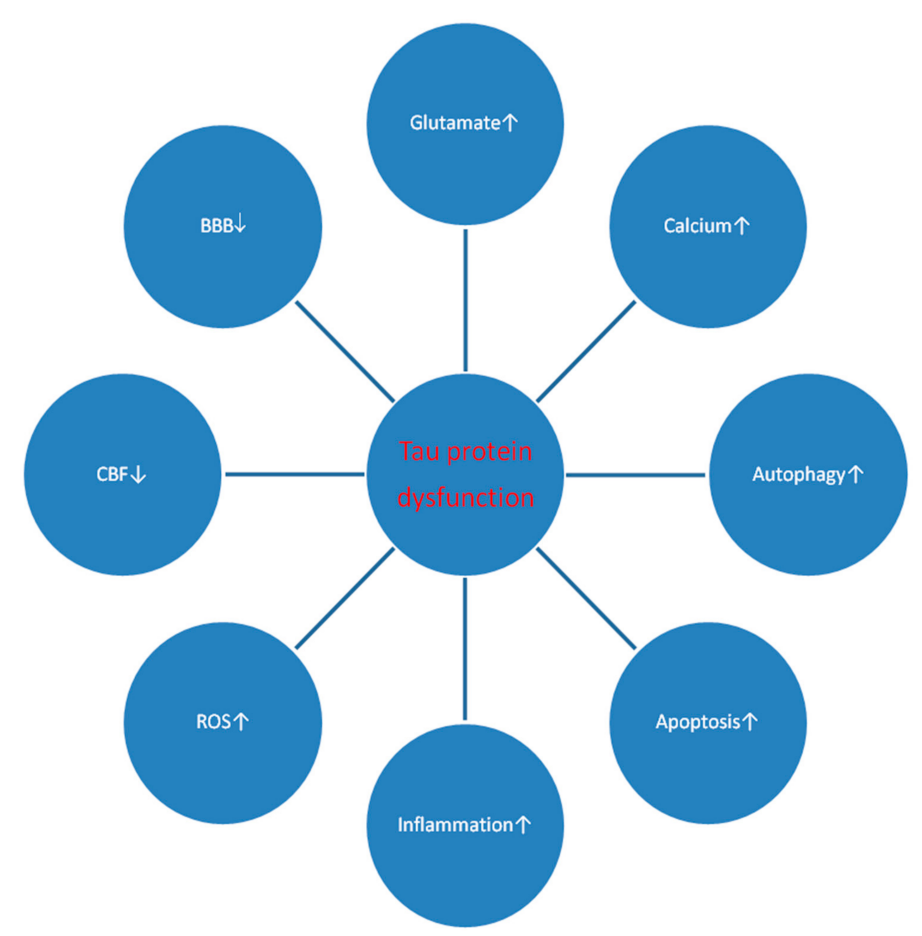

Figure 2. Potential regulatory mechanisms of dysfunctional tau protein in post-ischemic brain neuropathology. $\downarrow$ - decrease, $\uparrow$ - increase. BBB-blood-brain barrier, CBF-cerebral blood flow, ROS-reactive oxygen species. 


\section{Tau Protein Hyperphosphorylation Renders Cells More Resistant to Apoptosis?}

Hyperphosphorylated tau protein, most likely by competitive inhibition of GSK-3 phosphorylation of $\beta$-catenin, facilitates the action of $\beta$-catenin and other proteins, thus inhibiting the apoptosis pathway [90-94]. It was also shown that neurons with dephosphorylated tau protein were more susceptible to apoptosis [60]. The involvement of tau protein in the neuron viability was also observed in the cerebellar granule neurons [95]. These studies suggest that hyperphosphorylated tau protein may lead to the breakdown of acute apoptosis in neurons. Because adult neurons are rarely replenished, the failed apoptosis induced by the phosphorylation of the tau protein may be one of the evolving mechanisms that may allow neurons to survive an apoptotic attack and wait for a chance of self-repair. Although hyperphosphorylation of the tau protein can cause neuron escape from the apoptotic pathway and thus prevent the rapid loss of many neurons by the brain, nerve cells with hyperphosphorylated tau protein are nevertheless "sick" (Figures 2 and 3) and are no longer competent for normal physiological functions such as promoting microtubule assembly and maintaining normal axonal transport [96]. In addition, the prolonged survival time of these "sick" neuronal cells makes them less resistant to environmental influences, and also allows them to develop tangles from hyperphosphorylated tau protein (Table 1). Hyperphosphorylation of the tau protein leads to slow but progressive retrograde degeneration of neurons. Therefore, modulation of phosphorylation of tau protein at various stages of Alzheimer's disease and related tauopathies offers promising ways to save neurons from degeneration.

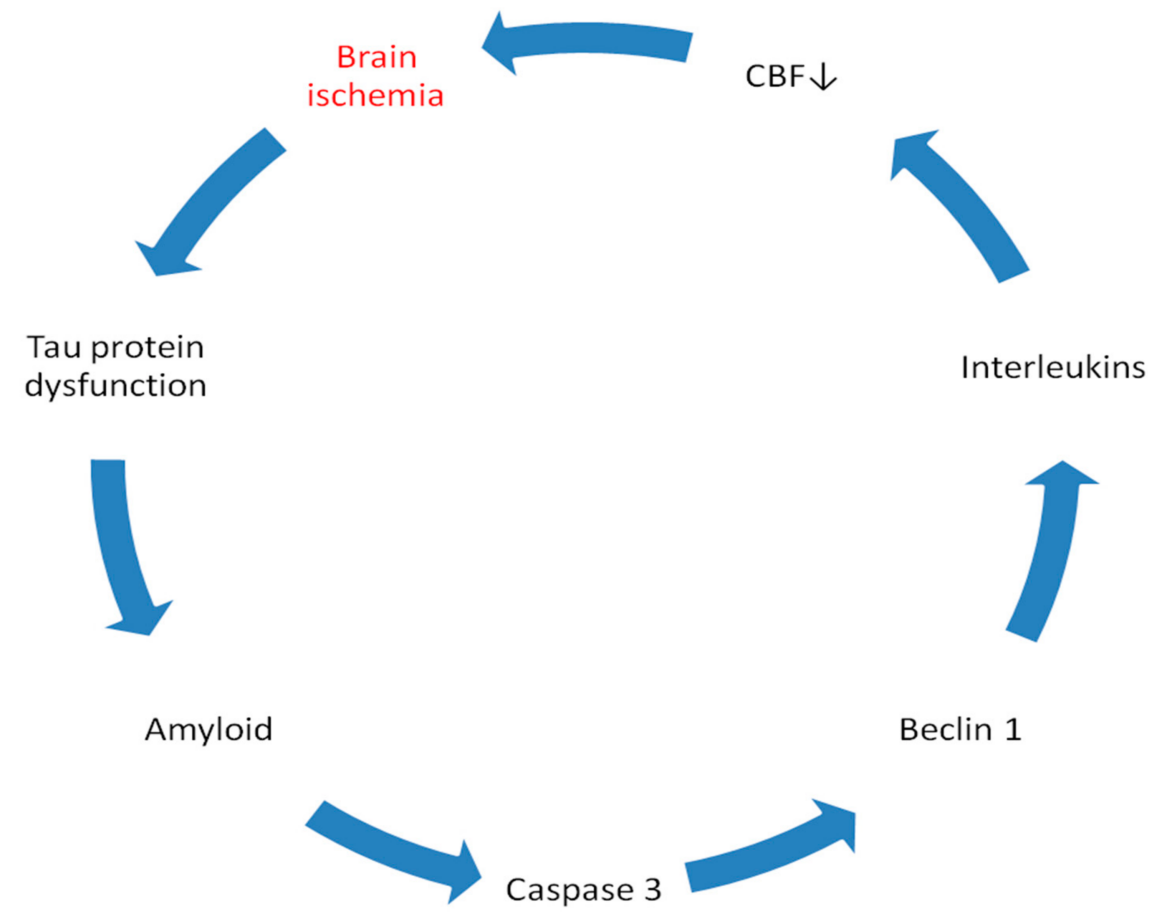

Figure 3. Cross talk between Alzheimer's disease-associated proteins during post-ischemic brain injury. Beclin 1-protein associated with autophagy. CBF $\downarrow$-decrease of cerebral blood flow.

\section{Hyperphosphorylated Tau Protein Good or Bad?}

The biological activity of the tau protein is regulated by its degree of phosphorylation; both hypoand hyperphosphorylation [16,97]. The harmful effect of tau protein is largely deduced from the fact that hyperphosphorylated tau protein is accidentally present in degenerate neurons in several tauopathies, and in particular in Alzheimer's disease and brain ischemia (Table 1). However, these correlations are not enough to conclude that hyperphosphorylated tau protein is the harbinger of cell death in Alzheimer's disease. Instead, some recent studies show that hyperphosphorylation of tau protein can be protective, especially when cells are exposed to acute injuries [96]. Quantitative analysis 
of neuronal loss as a function of disease duration revealed that the CA1 hippocampal neurons carrying neurofibrillary tangles can survive for decades [98]. In transgenic mouse models expressing human tau protein, the presence of tau protein filaments did not correlate directly with the death of individual neurons $[91-94,96]$ and, furthermore, formation of tau protein filaments seems neuroprotective $[99,100]$. These data suggest that the aggregation of hyperphosphorylated tau protein in the adult mammalian brain may be associated with neuroprotective mechanisms. There has been some controversy regarding the toxicity of the polymerized tau protein [97]. Some data show that tau protein aggregation is toxic to cells $[101,102]$. Conversely, some studies have shown that the polymerization of tau protein is not associated with toxic effects on cells. It has been found that the polymerized tau protein loses its biological activity with respect to binding to microtubules, while dephosphorylation of aberrantly hyperphosphorylated tau protein and paired helical filaments transforms them into a normal protein, restoring significantly the biological activity of the tau protein $[103,104]$. The reduction in the microtubule density in pyramidal neurons in the brains of Alzheimer's disease patients is not associated with the presence of paired helical filaments [105]. It has been found that the removal of the pattern-breaking sequences in microtubule binding repeats results in immediate aggregation of the tau protein and toxicity, but toxicity appeared without the requirement of fibril formation [106]. In transgenic P301L mice, neuronal death in the CA1 hippocampus region was prevented when suppressing the expression of the mutant tau protein gene and improvement in memory was observed without decreasing the number of neurofibrillary tangles $[107,108]$. Chronic treatment of transgenic P301L mice with ERK2 inhibitor resulted in a significant reduction in hyperphosphorylated tau protein and prevented motor impairment, but the number of neurofibrillary tangles did not decrease in the successfully treated group [109]. The formation of tau protein aggregates abolished the toxicity of soluble phosphorylated tau protein [99]. From these observations, it appears that the formation of paired helical filaments/neurofibrillary tangles from soluble hyperphosphorylated tau protein in neurons is a defense mechanism by which neurons seek to reduce the toxic activity of soluble hyperphosphorylated tau protein.

\section{Discussion}

This review shows the response of the tau protein gene and its products to brain ischemia with recirculation (Figures 2 and 3). The data revealed that after ischemic brain injury, the overexpression of the tau protein gene 2 days after ischemic episode began and correlated with a huge increase in plasma tau protein after ischemic injury [78,79] and extracellular space after brain injury [110], as well as with the hyperphosphorylation of tau protein in ischemic brain tissue (Table 1$)[49,54,57,85,87]$. The increased expression of the tau protein gene was parallel to the onset of delayed neuronal death in the hippocampus after ischemia [11,12,39]. A rise in tau protein levels in the brain and blood [77,79] was associated with a similar increase in the $\beta$-amyloid peptide level in the brain and serum after ischemia (Figure 3) [72,73], and this observation forecasted a worse clinical outcome. The increase in tau protein gene expression induced by ischemia at the onset of neuronal death in the hippocampus is parallel to the overexpression of the caspase 3 gene, which plays a role in neuronal death (Figure 3) [35]. The processes by which both the tau protein and caspase 3 kill the neurons of the hippocampus are not completely understood. Caspase ultimately cuts the tau protein into shorter forms [16]. Notably, studies have shown that activated caspase positively correlates with increased levels of truncated tau protein and the formation of neurofibrillary tangles [16]. In addition, cognitive deficits are negatively correlated with the level of tau protein shortened by caspase 3 [16]. The data suggest that when the tau protein undergoes ischemic translation, its hyperphosphorylation increases, which means that the hyperphosphorylation of the tau protein is driven by the substrate and the transcription levels are identical to the protein levels $[49,55]$. Other studies have shown elevated levels of Cdk5 in rats exposed to focal transient cerebral ischemia, confirming the above observations [49]. Enhancing the hyperphosphorylation of the tau protein level may be a consequence of the increased translation of the tau protein and the inhibition of tau protein degradation and/or blocked clearance. The inhibition of 
degradation is strongly supported by a reduction in the level of the autophagy gene expression during the onset of neuronal death in the hippocampus [35]. The immunocytochemical studies demonstrated that intraneuronal tau protein proteolysis is a sensitive, early marker of focal ischemic injury in the brain. The double labeled immunofluorescence experiments suggested that proteolysis of tau protein coincides with calpain activation. It was concluded that focal brain ischemia is associated with early microtubular proteolysis caused by calpain [111]. Data show that brain ischemia activates neuronal changes and death in the hippocampus in a manner dependent on tau protein, thus determining a new and important way to regulate the survival and/or death of post-ischemic neurons. Triggered pathological changes such as oxidative stress, apoptosis, autophagy, excitotoxicity, inflammation, endothelium, angiogenesis, and mitochondrial dysfunction of tau protein determine its potential regulatory mechanisms in ischemic stroke (Figure 2).

The presented facts confirm the opinion that brain ischemia with reperfusion plays a key role in the dysfunction of the tau protein in the brain and blood after ischemia. The expression of the tau protein gene and its protein level in brain tissue and plasma, which are increased after ischemic brain injury $[15,78,79]$, are involved together with a parallel generated amyloid (Figure 3 ) in the development of neuropathology characteristic of Alzheimer's disease after ischemia. One study proved that the regional redistribution of tau protein from the neuropil to neuronal perikarya in post-ischemic stroke model was thought to share similarity with that occurring in Alzheimer's disease [57]. It is highly likely that the modified tau protein additionally enhances ischemic neuronal damage after ischemia (Figure 3). The above data allow us to understand the acute and chronic processes during neuronal death and the development of slow and progressive brain atrophy after ischemic damage with dementia of the Alzheimer's disease phenotype [12,22,112,113]. After brain ischemia injury, an increase in blood tau protein levels was observed in patients [78,79]. Increased plasma tau protein levels correlated negatively with the clinical outcome after ischemic brain injury, which, in turn, reflected the severity of the ischemic stroke $[78,79]$. We can conclude that proteomic and genomic changes in tau protein, which are associated with Alzheimer's disease pathology, contribute to the neurodegeneration of the brain after ischemia with the development of the type of Alzheimer's disease dementia [12,22,112,113]. In the brain after ischemia with reperfusion, ischemia seems to favor the development of irreversible neurodegeneration of the Alzheimer's disease type with neuronal death [11], neuroinflammation [76], white matter changes, general brain atrophy, amyloid accumulation $[7,45]$ and dysfunctional tau protein (Figures 2 and 3) $[15,16]$. Although significant progress has recently been made in studying the pathogenicity of tau protein after brain injury due to ischemia and reperfusion, the key mechanisms/pathways involved in irreversible brain neurodegeneration induced by tau protein after ischemia are still unknown. It has also been shown that ischemia with reperfusion injures the brain, inducing neuronal death in the brain in a manner dependent on the tau protein (Figures 2 and 3) [16], thus defining a new and important way to regulate the survival or death of neurons. The relationship between tau protein associated with Alzheimer's disease and experimental cerebral ischemia and ischemic stroke in humans seems quite clear. The worldwide problem and the huge costs associated with human ischemic stroke clearly show that there is an urgent need to progress in the treatment of post-ischemic brain injury with irreversible consequences, such as the dementia of the Alzheimer's disease phenotype.

Although the role of ischemia in the hyperphosphorylation of tau protein is generally complex and requires further research, and tau protein is a relatively undervalued factor in ischemic stroke, we have reason to believe that determining the role of tau protein in cerebral ischemia may help to understand the basis for developing a new target for treatment of ischemic stroke (Table 1). It seems that these data confirm that the regulation of tau protein phosphorylation can be considered as a potential new therapeutic target after ischemic stroke.

According to observations from earlier and newer studies, it can be concluded that transient global and focal ischemia brain damage affects the modification of the tau protein at both the protein and gene level, leading to tau protein deposition as paired helical filaments, neurofibrillary tangle-like and neurofibrillary tangles in the brain (Table 1) [16]. The conclusions drawn from the analysis of 
ischemia-triggered Alzheimer's disease-related tau protein and its gene in the brain, which are part of the cause of neuronal death by generation of neurofibrillary tangle-like and/or neurofibrillary tangles, are crucial for the improvement of therapy of irreversible post-ischemic neurodegeneration. Because the accumulation of amyloid and tau protein is not the cause of Alzheimer's disease pathogenesis, as found in the NIA-AA Research Framework: towards the biological definition of Alzheimer's disease [114], it is understandable that advanced study is necessary in this area. Ultimately, the experimental models of ischemia-reperfusion brain damage used in the study of Alzheimer's disease seem to be a useful new approach to clarifying the role of folding proteins and their genes in neurodegenerative diseases such as cerebral ischemia and sporadic Alzheimer's disease [15,16,27-30,34,35,115-119].

Funding: This research received no external funding.

Acknowledgments: The authors acknowledge the financial support from the following institutions: the Mossakowski Medical Research Centre, Polish Academy of Sciences, Warsaw, Poland (T3-RP) and the Medical University of Lublin, Lublin, Poland (DS 475/19-SJC).

Conflicts of Interest: The authors declare no conflict of interest.

\section{References}

1. Honig, L.S.; Tang, M.X.; Albert, S.; Costa, R.; Luchsinger, J.; Manly, J.; Stern, Y.; Mayeux, R. Stroke and the risk of Alzheimer disease. Arch. Neurol. 2003, 60, 1707-1712. [CrossRef]

2. Gemmell, E.; Bosomworth, H.; Allan, L.; Hall, R.; Khundakar, A.; Oakley, A.E.; Deramecourt, V.; Polvikoski, T.M.; O'Brien, J.T.; Kalaria, R.N. Hippocampal neuronal atrophy and cognitive function in delayed poststroke and aging-related dementias. Stroke 2012, 43, 808-814. [CrossRef] [PubMed]

3. Bejot, Y.; Daubail, B.; Giroud, M. Epidemiology of stroke and transient ischemic attacks: Current knowledge and perspectives. Rev. Neurol. 2016, 172, 59-68. [CrossRef] [PubMed]

4. Mok, V.C.T.; Lam, B.Y.K.; Wang, Z.; Liu, W.; Au, L.; Leung, E.Y.L.; Chen, S.; Yang, J.; Chu, W.C.W.; Lau, A.Y.L.; et al. Delayed-onset dementia after stroke or transient ischemic attack. Alzheimers Dement. 2016, 12, 1167-1176. [CrossRef] [PubMed]

5. Cassella, C.R.; Jagoda, A. Ischemic stroke: Advances in diagnosis and management. Emerg. Med. Clin. N. Am. 2017, 35, 911-930. [CrossRef]

6. Kim, J.H.; Lee, Y. Dementia and death after stroke in older adults during a 10-year follow-up: Results from a competing risk model. J. Nutr. Health Aging 2018, 22, 297-301. [CrossRef]

7. Pluta, R.; Kida, E.; Lossinsky, A.S.; Golabek, A.A.; Mossakowski, M.J.; Wisniewski, H.M. Complete cerebral ischemia with short-term survival in rats induced by cardiac arrest. I. Extracellular accumulation of Alzheimer's beta-amyloid protein precursor in the brain. Brain Res. 1994, 649, 323-328. [CrossRef]

8. Jendroska, K.; Poewe, W.; Daniel, S.E.; Pluess, J.; Iwerssen-Schmidt, H.; Paulsen, J.; Barthel, S.; Schelosky, L.; Cervos-Navarro, J.; DeArmond, S.J. Ischemic stress induces deposition of amyloid beta immunoreactivity in human brain. Acta Neuropathol. 1995, 90, 461-466. [CrossRef]

9. Jendroska, K.; Hoffmann, O.M.; Patt, S. Amyloid beta peptide and precursor protein (APP) in mild and severe brain ischemia. Ann. N. Y. Acad. Sci. 1997, 826, 401-405. [CrossRef]

10. Wiśniewski, H.M.; Maślińska, D. Beta-protein immunoreactivity in the human brain after cardiac arrest. Folia. Neuropathol. 1996, 34, 65-71.

11. Pluta, R. The role of apolipoprotein $\mathrm{E}$ in the deposition of $\beta$-amyloid peptide during ischemia-reperfusion brain injury. A model of early Alzheimer's disease. Ann. N. Y. Acad. Sci. 2000, 903, 324-334. [CrossRef] [PubMed]

12. Pluta, R.; Ułamek, M.; Jabłoński, M. Alzheimer's mechanisms in ischemic brain degeneration. Anat. Rec. 2009, 292, 1863-1881. [CrossRef] [PubMed]

13. Qi, J.; Wu, H.; Yang, Y.; Wand, D.; Chen, Y.; Gu, Y.; Liu, T. Cerebral ischemia and Alzheimer's disease: The expression of amyloid- $\beta$ and apolipoprotein $\mathrm{E}$ in human hippocampus. J. Alzheimers Dis. 2007, 12, 335-341. [CrossRef]

14. Maślińska, D.; Laure-Kamionowska, M.; Taraszewska, A.; Deręgowski, K.; Maśliński, S. Immunodistribution of amyloid beta protein (A $\beta$ ) and advanced glycation end-product receptors (RAGE) in choroid plexus and ependyma of resuscitated patients. Folia. Neuropathol. 2011, 49, 295-300. [PubMed] 
15. Pluta, R.; Bogucka-Kocka, A.; Ułamek-Kozioł, M.; Bogucki, J.; Januszewski, S.; Kocki, J.; Czuczwar, S.J. Ischemic tau protein gene induction as an additional key factor driving development of Alzheimer's phenotype changes in CA1 area of hippocampus in an ischemic model of Alzheimer's disease. Pharmacol. Rep. 2018, 70, 881-884. [CrossRef]

16. Pluta, R.; Ułamek-Kozioł, M.; Januszewski, S.; Czuczwar, S.J. Tau protein dysfunction after brain ischemia. J. Alzheimers Dis. 2018, 66, 429-437. [CrossRef]

17. Snowdon, D.A.; Greiner, L.H.; Mortimer, J.A.; Riley, K.P.; Greiner, P.A.; Markesbery, W.R. Brain infarction and the clinical expression of Alzheimer disease: The Nun Study. JAMA 1997, 277, 813-817. [CrossRef]

18. Kuroiwa, T.; Bonnekoh, P.; Hossmann, K.A. Locomotor hyperactivity and hippocampal CA1 injury after transient forebrain ischemia in gerbils. Neurosci. Lett. 1991, 122, 141-144. [CrossRef]

19. Karasawa, Y.; Araki, H.; Otomo, S. Changes in locomotor activity and passive avoidance task performance induced by cerebral ischemia in mongolian gerbils. Stroke 1994, 25, 645-650. [CrossRef]

20. Ishibashi, S.; Kuroiwa, T.; LiYuan, S.; Katsumata, N.; Li, S.; Endo, S.; Mizusawa, H. Long-term cognitive and neuropsychological symptoms after global cerebral ischemia in Mongolian gerbils. Acta Neurochir. 2006, 96, 299-302.

21. De la Tremblaye, B.P.; Plamondon, H. Impaired conditioned emotional response and object recognition are concomitant to neuronal damage in the amygdale and perirhinal cortex in middle-aged ischemic rats. Behav. Brain Res. 2011, 219, 227-233. [CrossRef] [PubMed]

22. Kiryk, A.; Pluta, R.; Figiel, I.; Mikosz, M.; Ułamek, M.; Niewiadomska, G.; Jabłoński, M.; Kaczmarek, L. Transient brain ischemia due to cardiac arrest causes irreversible long-lasting cognitive injury. Behav. Brain Res. 2011, 219, 1-7. [CrossRef] [PubMed]

23. Li, J.; Wang, Y.J.; Zhang, M.; Fang, C.Q.; Zhou, H.D. Cerebral ischemia aggravates cognitive impairment in a rat model of Alzheimer's disease. Life Sci. 2011, 89, 86-92. [CrossRef] [PubMed]

24. Pluta, R.; Jolkkonen, J.; Cuzzocrea, S.; Pedata, F.; Cechetto, D.; Popa-Wagner, A. Cognitive impairment with vascular impairment and degeneration. Curr. Neurovasc. Res. 2011, 8, 342-350. [CrossRef]

25. Cohan, C.H.; Neumann, J.T.; Dave, K.R.; Alekseyenko, A.; Binkert, M.; Stransky, K.; Lin, H.W.; Barnes, C.A.; Wright, C.B.; Perez-Pinzon, M.A. Effect of cardiac arrest on cognitive impairment and hippocampal plasticity in middle-aged rats. PLoS ONE 2015, 10, e0124918. [CrossRef]

26. Pluta, R.; Furmaga-Jabłońska, W.; Maciejewski, R.; Ułamek-Kozioł, M.; Jabłoński, M. Brain ischemia activates $\beta$ - and gamma-secretase cleavage of amyloid precursor protein: Significance in sporadic Alzheimer's disease. Mol. Neurobiol. 2013, 47, 425-434. [CrossRef]

27. Kocki, J.; Ułamek-Kozioł, M.; Bogucka-Kocka, A.; Januszewski, S.; Jabłoński, M.; Gil-Kulik, P.; Brzozowska, J.; Petniak, A.; Furmaga-Jabłońska, W.; Bogucki, J.; et al. Dysregulation of amyloid precursor protein, $\beta$-secretase, presenilin 1 and 2 genes in the rat selectively vulnerable CA1 subfield of hippocampus following transient global brain ischemia. J. Alzheimers Dis. 2015, 47, 1047-1056. [CrossRef]

28. Pluta, R.; Kocki, J.; Ułamek-Kozioł, M.; Bogucka-Kocka, A.; Gil-Kulik, P.; Januszewski, S.; Jabłoński, M.; Petniak, A.; Brzozowska, J.; Bogucki, J.; et al. Alzheimer-associated presenilin 2 gene is dysregulated in rat medial temporal lobe cortex after complete brain ischemia due to cardiac arrest. Pharmacol. Rep. 2016, 68, 155-161. [CrossRef]

29. Pluta, R.; Kocki, J.; Ułamek-Kozioł, M.; Petniak, A.; Gil-Kulik, P.; Januszewski, S.; Bogucki, J.; Jabłoński, M.; Brzozowska, J.; Furmaga-Jabłońska, W.; et al. Discrepancy in expression of $\beta$-secretase and amyloid- $\beta$ protein precursor in Alzheimer-related genes in the rat medial temporal lobe cortex following transient global brain ischemia. J. Alzheimers Dis. 2016, 51, 1023-1031. [CrossRef]

30. Ułamek-Kozioł, M.; Kocki, J.; Bogucka-Kocka, A.; Petniak, A.; Gil-Kulik, P.; Januszewski, S.; Bogucki, J.; Jabłoński, M.; Furmaga-Jabłońska, W.; Brzozowska, J.; et al. Dysregulation of autophagy, mitophagy and apoptotic genes in the medial temporal lobe cortex in an ischemic model of Alzheimer's disease. J. Alzheimers Dis. 2016, 54, 113-121. [CrossRef]

31. Ułamek-Kozioł, M.; Pluta, R.; Januszewski, S.; Kocki, J.; Bogucka-Kocka, A.; Czuczwar, S.J. Expression of Alzheimer's disease risk genes in ischemic brain degeneration. Pharmacol. Rep. 2016, 68, 1345-1349. [CrossRef]

32. Ułamek-Kozioł, M.; Pluta, R.; Bogucka-Kocka, A.; Januszewski, S.; Kocki, J.; Czuczwar, S.J. Brain ischemia with Alzheimer phenotype dysregulates Alzheimer's disease-related proteins. Pharmacol. Rep. 2016, 68, 582-591. [CrossRef] 
33. Pluta, R.; Ułamek-Kozioł, M.; Januszewski, S.; Czuczwar, S.J. Dysregulation of Alzheimer's disease-related genes and proteins following cardiac arrest. Folia. Neuropathol. 2017, 55, 283-288. [CrossRef]

34. Salminen, A.; Kauppinen, A.; Kaarniranta, K. Hypoxia/ischemia activate processing of amyloid precursor protein: Impact of vascular dysfunction in the pathogenesis of Alzheimer's disease. J. Neurochem. 2017, 140, 536-549. [CrossRef]

35. Ułamek-Kozioł, M.; Kocki, J.; Bogucka-Kocka, A.; Januszewski, S.; Bogucki, J.; Czuczwar, S.J.; Pluta, R. Autophagy, mitophagy and apoptotic gene changes in the hippocampal CA1 area in a rat ischemic model of Alzheimer's disease. Pharmacol. Rep. 2017, 69, 1289-1294. [CrossRef]

36. Pluta, R.; Ułamek-Kozioł, M. Alzheimer's disease associated genes and their products in brain ischemia: Impact of ischemia on the pathogenesis of Alzheimer's disease. J. Ageing Restor. Med. 2018, 1, 19-27.

37. Pluta, R.; Ułamek-Kozioł, M.; Januszewski, S.; Czuczwar, S.J. From brain ischemia to Alzheimer-like neurodegeneration. Neuropsychiatry 2018, 8, 1708-1714. [CrossRef]

38. Pluta, R.; Jabłoński, M.; Ułamek-Kozioł, M.; Kocki, J.; Brzozowska, J.; Januszewski, S.; Furmaga-Jabłońska, W.; Bogucka-Kocka, A.; Maciejewski, R.; Czuczwar, S.J. Sporadic Alzheimer's disease begins as episodes of brain ischemia and ischemically dysregulated Alzheimer's disease genes. Mol. Neurobiol. 2013, 48, 500-515. [CrossRef]

39. Pluta, R. Experimental model of neuropathological changes characteristic for Alzheimer's disease. Folia. Neuropathol. 1997, 35, 94-98.

40. Pluta, R. Is the ischemic blood-brain barrier insufficiency responsible for full-blown Alzheimer's disease? Neurol. Res. 2006, 28, 266-271. [CrossRef]

41. Pluta, R.; Ułamek, M. Brain amyloidosis following ischemia-reperfusion injury. Curr. Trends Neurol. 2006, 2, $41-46$.

42. Pluta, R. Role of ischemic blood-brain barrier on amyloid plaques development in Alzheimer's disease brain. Curr. Neurovasc. Res. 2007, 4, 121-129. [CrossRef]

43. Pluta, R. Ischemia-Reperfusion Pathways in Alzheimer's Disease; Nova Science Publishers, Inc.: New York, NY, USA, 2007.

44. Pluta, R.; Ułamek, M. Brain ischemia and ischemic blood-brain barrier as etiological factors in sporadic Alzheimer's disease. Neuropsychiatr. Dis. Treat 2008, 4, 855-864. [CrossRef] [PubMed]

45. Pluta, R.; Januszewski, S.; Jabłoński, M.; Ułamek, M. Factors in creepy delayed neuronal death in hippocampus following brain ischemia-reperfusion injury with longterm survival. Acta Neurochir. 2010, 106, 37-41.

46. Pluta, R.; Ułamek, M.; Jabłoński, M. Consideration of the ischaemic basis and treatment of Alzheimer's disease. Folia. Neuropathol. 2010, 48, 11-26.

47. Chen, X.; Jiang, H. Tau as a potential therapeutic target for ischemic stroke. Aging 2019, 11, 12827-12843. [CrossRef]

48. Shackelford, D.A.; Yeh, R.Y. Dephosphorylation of tau during transient forebrain ischemia in the rat. Mol. Chem. Neuropathol. 1998, 34, 103-120. [CrossRef]

49. Wen, Y.; Yang, S.H.; Liu, R.; Perez, E.J.; Brun-Ziukemagel, A.M.; Koulen, P.; Simpkins, J.W. Cdk5 is involved in NFT-like tauopathy induced by transient cerebral ischemia in female rats. Biochim. Biophys. Acta 2007, 1772, 473-483. [CrossRef]

50. Stamer, K.; Vogel, R.; Thies, E.; Mandelkow, E.; Mandelkow, E.M. Tau blocks traffic of organelles, neurofilaments, and APP vesicles in neurons and enhances oxidative stress. J. Cell Biol. 2002, 156, 1051-1063. [CrossRef]

51. Kato, T.; Hirano, A.; Katagiri, T.; Sasaki, H.; Yamada, S. Neurofibrillary tangle formation in the nucleus basalis of Meynert ipsilateral to a massive cerebral infarct. Ann. Neurol. 1988, 23, 620-623. [CrossRef]

52. Khan, S.; Yuldasheva, N.Y.; Batten, T.F.C.; Pickles, A.R.; Kellett, K.A.B.; Saha, S. Tau pathology and neurochemical changes associated with memory dysfunction in an optimized murine model of global cerebral ischaemia - A potential model for vascular dementia? Neurochem. Int. 2018, 118, 134-144. [CrossRef] [PubMed]

53. Basurto-Islas, G.; Gu, J.H.; Tung, Y.C.; Liu, F.; Iqbal, K. Mechanism of tau hyperphosphorylation involving lysosomal enzyme sparagines endopeptidase in a mouse model of brain ischemia. J. Alzheimers Dis. 2018, 63, 821-833. [CrossRef] [PubMed]

54. Wen, Y.; Yang, S.; Liu, R.; Simpkins, J.W. Transient cerebral ischemia induces site-specific hyperphosphorylation of tau protein. Brain Res. 2004, 1022, 30-38. [CrossRef] [PubMed] 
55. Wen, Y.; Yang, S.; Liu, R.; Brun-Zinkernagel, A.M.; Koulen, P.; Simpkins, J.W. Transient cerebral ischemia induces aberrant neuronal cell cycle re-entry and Alzheimer's disease-like tauopathy in female rats. J. Biol. Chem. 2007, 279, 22684-22692. [CrossRef]

56. Kovalska, M.; Tothova, B.; Kovalska, L.; Tatarkova, Z.; Kalenska, D.; Tomascova, A.; Adamkov, M.; Lehotsky, J. Association of induced hyperhomocysteinemia with Alzheimer's disease-like neurodegeneration in rat cortical neurons after global ischemia-reperfusion injury. Neurochem. Res. 2018, 43, 1766-1778. [CrossRef]

57. Fujii, H.; Takahashi, T.; Mukai, T.; Tanaka, S.; Hosomi, N.; Maruyama, H.; Sakai, N.; Matsumoto, M. Modifications of tau protein after cerebral ischemia and reperfusion in rats are similar to those occurring in Alzheimer's disease - Hyperphosphorylation and cleavage of 4- and 3-repeat tau. J. Cereb. Blood Flow Metab. 2017, 37, 2441-2457. [CrossRef]

58. Morioka, M.; Kawano, T.; Yano, S.; Kai, Y.; Tsuiki, H.; Yoshinaga, Y.; Matsumoto, J.; Maeda, T.; Hamada, J.; Yamamoto, H.; et al. Hyperphosphorylation at serine 199/202 of tau factor in the gerbil hippocampus after transient forebrain ischemia. Biochem. Biophys. Res. Commun. 2006, 347, 273-278. [CrossRef]

59. Uchihara, T.; Tsuchiya, K.; Kondo, H.; Hayama, T.; Ikeda, K. Widespread appearance of Alz-50 immunoreactive neurons in the human brain with cerebral infarction. Stroke 1995, 26, 2145-2148. [CrossRef]

60. Rametti, A.; Esclaire, F.; Yardin, C.; Terro, F. Linking alterations in tau phosphorylation and cleavage during neuronal apoptosis. J. Biol. Chem. 2004, 279, 54518-54528. [CrossRef]

61. Liao, G.; Zhou, M.; Cheung, S.; Galeano, J.; Nguyen, N.; Baudry, M.; Bi, X. Reduced early hypoxic/ischemic brain damage is associated with increased GLT-1 levels in mice expressing mutant (P301L) human tau. Brain Res. 2009, 1247, 159-170. [CrossRef]

62. Mailliot, C.; Podevin-Dimster, V.; Rosenthal, R.E.; Sergeant, N.; Delacourte, A.; Fiskum, G.; Buee, L. Rapid tau protein dephosphorylation and differential rephosphorylation during cardiac arrest-induced cerebral ischemia and reperfusion. J. Cereb. Blood Flow Metab. 2000, 20, 543-549. [CrossRef] [PubMed]

63. Bi, M.; Gladbach, A.; van Eersel, J.; Ittner, A.; Przybyla, M.; van Hummel, A.; Chua, S.W.; van der Hoven, J.; Lee, W.S.; Muller, J.; et al. Tau exacerbates excitotoxic brain damage in an animal model of stroke. Nat. Commun. 2017, 8, 473. [CrossRef] [PubMed]

64. Dewar, D.; Graham, D.I.; Teasdale, G.M.; McCulloch, J. Alz-50 and ubiquitin immunoreactivity is induced by permanent focal cerebral ischaemia in the cat. Acta Neuropathol. 1993, 86, 623-629. [CrossRef] [PubMed]

65. Dewar, D.; Graham, D.I.; Teasdale, G.M.; McCulloch, J. Cerebral ischemia induces alterations in tau and ubiquitin proteins. Dementia 1994, 5, 168-173. [CrossRef]

66. Geddes, J.W.; Schwab, C.; Craddock, S.; Wilson, J.L.; Pettigrew, L.C. Alterations in tau immunostaining in the rat hippocampus following transient cerebral ischemia. J. Cereb. Blood Flow Metab. 1994, 14, 554-564. [CrossRef]

67. Dewar, D.; Dawson, D. Tau protein is altered by focal cerebral ischaemia in the rat: An immunohistochemical and immunoblotting study. Brain Res. 1995, 684, 70-78. [CrossRef]

68. Irving, E.A.; Nicoll, J.; Graham, D.I.; Dewar, D. Increased tau immunoreactivity in oligodendrocytes following human stroke and head injury. Neurosci. Lett. 1996, 213, 189-192. [CrossRef]

69. Irving, E.A.; Yatsushiro, K.; McCulloch, J.; Dewar, D. Rapid alteration of tau in oligodendrocytes after focal ischemic injury in the rat: Involvement of free radicals. J. Cereb. Blood Flow Metab. 1997, 17, 612-622. [CrossRef]

70. Sinigaglia-Coimbra, R.; Cavalheiro, E.A.; Coimbra, C.G. Postischemic hypertermia induces Alzheimer like pathology in the rat brain. Acta Neuropathol. 2002, 103, 444-452.

71. Uchihara, T.; Nakamura, A.; Arai, T.; Ikeda, K.; Tsuchiya, K. Microglial tau undergoes phosphorylation independent modification after ischemia. Glia 2004, 45, 180-187. [CrossRef]

72. Lee, P.H.; Bang, O.Y.; Hwang, E.M.; Lee, J.S.; Joo, U.S.; Mook-Jung, I.; Huh, K. Circulating beta amyloid protein is elevated in patients with acute ischemic stroke. J. Neural. Transm. 2005, 112, 1371-1379. [CrossRef] [PubMed]

73. Zetterberg, H.; Mörtberg, E.; Song, L.; Chang, L.; Provuncher, G.K.; Patel, P.P.; Ferrell, E.; Fournier, D.R.; Kan, C.W.; Campbell, T.G.; et al. Hypoxia due to cardiac arrest induces a time-dependent increase in serum amyloid $\beta$ levels in humans. PLoS One 2011, 6, e28263. [CrossRef] [PubMed]

74. Ramos-Cejudo, J.; Wisniewski, T.; Marmar, C.; Zetterberg, H.; Blennow, K.; de Leon, M.J.; Fossati, S. Traumatic brain injury and Alzheimer's disease: The cerebrovascular link. E. Bio. Med. 2018, 28, 21-30. [CrossRef] [PubMed] 
75. Li, P.; Stetler, R.A.; Leak, R.K.; Shi, Y.; Li, Y.; Yu, W.; Bennett, M.V.L.; Chen, J. Oxidative stress and DNA damage after cerebral ischemia: Potential therapeutic targets to repair the genome and improve stroke recovery. Neuropharmacology 2018, 134, 208-217. [CrossRef] [PubMed]

76. Sekeljic, V.; Bataveljic, D.; Stamenkovic, S.; Ułamek, M.; Jabłoński, M.; Radenovic, L.; Pluta, R.; Andjus, P.R. Cellular markers of neuroinflammation and neurogenesis after ischemic brain injury in the long-term survival rat model. Brain Struct. Funct. 2012, 217, 411-420. [CrossRef] [PubMed]

77. Michalicova, A.; Banks, W.A.; Legath, J.; Kovac, A. Tauopathies - focus on changes at the neurovascular unit. Curr. Alzheimer Res. 2017, 14, 790-801. [CrossRef] [PubMed]

78. Mörtberg, E.; Zetterberg, H.; Nordmark, J.; Blennow, K.; Catry, C.; Decraemer, H.; Vanmechelen, E.; Rubertsson, S. Plasma tau protein in comatose patients after cardiac arrest treated with therapeutic hypothermia. Acta Anaesthesiol. Scand. 2011, 55, 1132-1138. [CrossRef]

79. Randall, J.; Mörtberg, E.; Provuncher, G.K.; Fournier, D.R.; Duffy, D.C.; Rubertsson, S.; Blennow, K.; Zetterberg, H.; Wilson, D.H. Tau proteins in serum predict neurological outcome after hypoxic brain injury from cardiac arrest: Results of a pilot study. Resuscitation 2013, 84, 351-356. [CrossRef]

80. Banks, W.A.; Kovac, A.; Majerova, P.; Bullock, K.M.; Shi, M.; Zhang, J. Tau proteins cross the blood-brain barrier. J. Alzheimers Dis. 2017, 55, 411-419. [CrossRef]

81. Pluta, R.; Barcikowska, M.; Januszewski, S.; Misicka, A.; Lipkowski, A.W. Evidence of blood- brain barrier permeability/leakage for circulating human Alzheimer's $\beta$-amyloid-(1-42)-peptide. Neuro. Rep. 1996, 7, 1261-1265.

82. Pluta, R. Blood-brain barrier dysfunction and amyloid precursor protein accumulation in microvascular compartment following ischemia-reperfusion brain injury with 1-year survival. Acta Neurochir. 2003, 86, 117-122.

83. Pluta, R. Pathological opening of the blood-brain barrier to horseradish peroxidase and amyloid precursor protein following ischemia-reperfusion brain injury. Chemotherapy 2005, 51, 223-226. [CrossRef] [PubMed]

84. Pluta, R.; Ułamek, M.; Januszewski, S. Micro-blood-brain barrier openings and cytotoxic fragments of amyloid precursor protein accumulation in white matter after ischemic brain injury in long-lived rats. Acta Neurochir. 2006, 96, 267-271.

85. Pluta, R.; Januszewski, S.; Ułamek, M. Ischemic blood-brain barrier and amyloid in white matter as etiological factors in leukoaraiosis. Acta Neurochir. 2008, 102, 353-356.

86. Pluta, R.; Ułamek-Kozioł, M.; Kocki, J.; Bogucki, J.; Januszewski, S.; Bogucka-Kocka, A.; Czuczwar, S.J. Expression of the tau protein and amyloid protein precursor processing genes in the CA3 area of the hippocampus in the ischemic model of Alzheimer's disease in the rat. Mol. Neurobiol. 2020, in press. [CrossRef]

87. Majd, S.; Power, J.H.; Koblar, S.A.; Grantham, H.J. Early glycogen synthase kinase-3 and protein phosphatase 2A independent tau dephosphorylation during global brain ischaemia and reperfusion following cardiac arrest and the role of the adenosine monophosphate kinase pathway. Eur. J. Neurosci. 2016, 44, 1987-1997.

88. Pluta, R.; Salińska, E.; Puka, M.; Stafiej, A.; Lazarewicz, J.W. Early changes in extracellular amino acids and calcium concentrations in rabbit hippocampus following complete 15-min cerebral ischemia. Resuscitation 1988, 16, 193-210. [CrossRef]

89. Tuo, Q.Z.; Lei, P.; Jackman, K.A.; Li, X.L.; Xiong, H.; Li, X.L.; Liuyang, Z.Y.; Roisman, L.; Zhang, S.T.; Ayton, S.; et al. Tau mediated iron export prevents ferroptotic damage after ischemic stroke. Mol. Psychiatry 2017, 22, 1520-1530. [CrossRef]

90. Raina, A.K.; Hochman, A.; Ickes, H.; Zhu, X.; Ogawa, O.; Cash, A.D.; Shimohama, S.; Perry, G.; Smith, M.A. Apoptotic promoters and inhibitors in Alzheimer's disease: Who wins out? Prog. Neuropsychopharmacol. Biol. Psychiatry 2003, 27, 251-254. [CrossRef]

91. Liu, X.A.; Liao, K.; Liu, R.; Wang, H.H.; Zhang, Y.; Zhang, Q.; Wang, Q.; Li, H.L.; Tian, Q.; Wang, J.Z. Tau dephosphorylation potentiates apoptosis by mechanisms involving a failed dephosphorylation/activation of Bcl-2. J. Alzheimers Dis. 2010, 19, 953-962. [CrossRef]

92. Liu, G.P.; Wei, W.; Zhou, X.; Zhang, Y.; Shi, H.H.; Yin, J.; Yao, X.Q.; Peng, C.X.; Hu, J.; Wang, Q.; et al. I(2) (PP2A) regulates p53 and Akt correlatively and leads the neurons to abort apoptosis. Neurobiol. Aging 2012, 33, 254-264. [CrossRef] [PubMed] 
93. Wang, Z.F.; Yin, J.; Zhang, Y.; Zhu, L.Q.; Tian, Q.; Wang, X.C.; Li, H.L.; Wang, J.Z. Overexpression of tau proteins antagonizes amyloid-beta-potentiated apoptosis through mitochondria caspase-3 pathway in N2a cells. J. Alzheimers Dis. 2010, 20, 145-157. [CrossRef] [PubMed]

94. Wang, H.H.; Li, H.L.; Liu, R.; Zhang, Y.; Liao, K.; Wang, Q.; Wang, J.Z.; Liu, S.J. Tau overexpression inhibits cell apoptosis with the mechanisms involving multiple viability-related factors. J. Alzheimers Dis. 2010, 21, 167-179. [CrossRef] [PubMed]

95. Amadoro, G.; Serafino, A.L.; Barbato, C.; Ciotti, M.T.; Sacco, A.; Calissano, P.; Canu, N. Role of N-terminal tau domain integrity on the survival of cerebellar granule neurons. Cell Death Differ. 2004, 11, 217-230. [CrossRef] [PubMed]

96. Wang, J.Z.; Xia, Y.Y.; Grundke-Iqbal, I.; Iqbal, K. Abnormal hyperphosphorylation of tau: Sites, regulation, and molecular mechanism of neurofibrillary degeneration. J. Alzheimers Dis. 2013, 33, S123-S139. [CrossRef] [PubMed]

97. Avila, J.; Santa-Maria, I.; Perez, M.; Hernandez, F.; Moreno, F. Tau phosphorylation, aggregation, and cell toxicity. J. Biomed. Biotechnol. 2006, 74539. [CrossRef]

98. Morsch, R.; Simon, W.; Coleman, P.D. Neurons may live for decades with neurofibrillary tangles. J. Neuropathol. Exp. Neurol. 1999, 58, 188-197. [CrossRef]

99. Andorfer, C.; Acker, C.M.; Kress, Y.; Hof, P.R.; Duff, K.; Davies, P. Cell-cycle reentry and cell death in transgenic mice expressing non mutant human tau isoforms. J. Neurosci. 2005, 25, 5446-5454. [CrossRef]

100. Alonso, A.D.; Li, B.; Grundke-Iqbal, I.; Iqbal, K. Polymerization of hyperphosphorylated tau into filaments eliminates its inhibitory activity. Proc. Natl. Acad. Sci. USA 2006, 23, 8864-8869. [CrossRef]

101. Khlistunova, I.; Biernat, J.; Wang, Y.; Pickhardt, M.; von Bergen, M.; Gazova, Z.; Mandelkow, E.; Mandelkow, E.M. Inducible expression of tau repeat domain in cell models of tauopathy: Aggregation is toxic to cells but can be reversed by inhibitor drugs. J. Biol. Chem. 2006, 281, 1205-1214. [CrossRef]

102. Wang, Y.P.; Biernat, J.; Pickhardt, M.; Mandelkow, E.; Mandelkow, E.M. Stepwise proteolysis liberates tau fragments that nucleate the Alzheimer-like aggregation of full-length tau in a neuronal cell model. Proc. Natl. Acad. Sci. USA 2007, 104, 10252-10257. [CrossRef] [PubMed]

103. Wang, J.Z.; Gong, C.X.; Zaidi, T.; Grundke-Iqbal, I.; Iqbal, K. Dephosphorylation of Alzheimer paired helical filaments by protein phosphatase-2A and -2B. J. Biol. Chem. 1995, 270, 4854-4860. [CrossRef] [PubMed]

104. Wang, J.Z.; Grundke-Iqbal, I.; Iqbal, K. Restoration of biological activity of Alzheimer abnormally phosphorylated tau by dephosphorylation with protein phosphatase-2A, -2B and -1. Brain Res. Mol. Brain Res. 1996, 38, 200-208. [CrossRef]

105. Cash, A.D.; Aliev, G.; Siedlak, S.L.; Nunomura, A.; Fujioka, H.; Zhu, X.; Raina, A.K.; Vinters, H.V.; Tabaton, M.; Johnson, A.B.; et al. Microtubule reduction in Alzheimer's disease and aging is independent of tau filament formation. Am. J. Pathol. 2003, 162, 1623-1627. [CrossRef]

106. Iliev, A.I.; Ganesan, S.; Bunt, G.; Wouters, F.S. Removal of pattern-breaking sequences in microtubule binding repeats produces instantaneous tau aggregation and toxicity. J. Biol. Chem. 2006, 281, 37195-37204. [CrossRef]

107. Santacruz, K.; Lewis, J.; Spires, T.; Paulson, J.; Kotilinek, L.; Ingelsson, M.; Guimaraes, A.; DeTure, M.; Ramsden, M.; McGowan, E.; et al. Tau suppression in a neurodegenerative mouse model improves memory function. Science 2005, 309, 476-481. [CrossRef]

108. Allen, B.; Ingram, E.; Takao, M.; Smith, M.J.; Jakes, R.; Virdee, K.; Yoshida, H.; Holzer, M.; Craxton, M.; Emson, P.C.; et al. Abundant tau filaments and nonapoptotic neurodegeneration in transgenic mice expressing human P301S tau protein. J. Neurosci. 2002, 22, 9340-9351. [CrossRef]

109. Le Corre, S.; Klafki, H.W.; Plesnila, N.; Hubinger, G.; Obermeier, A.; Sahagun, H.; Monse, B.; Seneci, P.; Lewis, J.; Eriksen, J.; et al. An inhibitor of tau hyperphosphorylation prevents severe motor impairments in tau transgenic mice. Proc. Natl. Acad. Sci. USA 2006, 103, 9673-9678. [CrossRef]

110. Magnoni, S.; Esparza, T.J.; Conte, V.; Carbonara, M.; Carrabba, G.; Holtzman, D.M.; Zipfel, G.J.; Stocchetti, N.; Brody, D.L. Tau elevations in the brain extracellular space correlate with reduced amyloid- $\beta$ levels and predict adverse clinical outcomes after severe traumatic brain injury. Brain 2012, 135, 1268-1280. [CrossRef]

111. Pettigrew, L.C.; Holtz, M.L.; Craddock, S.D.; Minger, S.L.; Hall, N.; Geddes, J.W. Microtubular proteolysis in focal cerebral ischemia. J. Cereb. Blood Flow Metab. 1996, 16, 1189-1202. [CrossRef]

112. Krajewski, S.; Mai, J.K.; Krajewska, M.; Sikorska, M.; Mossakowski, M.J.; Reed, J.C. Upregulation of bax protein levels in neurons following cerebral ischemia. J. Neurosci. 1995, 15, 6364-6376. [CrossRef] [PubMed] 
113. Sadowski, M.; Wisniewski, H.M.; Jakubowska-Sadowska, K.; Tarnawski, M.; Lazarewicz, J.W.; Mossakowski, M.J. Pattern of neuronal loss in the rat hippocampus following experimental cardiac arrest-induced ischemia. J. Neurol. Sci. 1999, 168, 13-20. [CrossRef]

114. Jack, C.R.; Bennett, D.A.; Blennow, K.; Carrillo, M.C.; Dunn, B.; Haeberlein, S.B.; Holtzman, D.M.; Jagust, W.; Jessen, F.; Karlawish, J.; et al. NIA-AA Research Framework: Toward a biological definition of Alzheimer's disease. Alzheimers Dement. 2018, 14, 535-562. [CrossRef] [PubMed]

115. Pluta, R.; Jabłoński, M.; Czuczwar, S.J. Postischemic dementia with Alzheimer phenotype: Selectively vulnerable versus resistant areas of the brain and neurodegeneration versus $\beta$-amyloid peptide. Folia. Neuropathol. 2012, 50, 101-109.

116. Pluta, R. Brain Ischemia: Alzheimer's Disease Mechanisms; Nova Science Publishers, Inc.: New York, NY, USA, 2019.

117. Pluta, R.; Ułamek-Kozioł, M. The role of degenerative pathways in the development of irreversible consequences after brain ischemia. Neural. Regen. Res. 2019, 14, 982-983. [CrossRef]

118. Pluta, R.; Ułamek-Kozioł, M.; Januszewski, S.; Czuczwar, S.J. Amyloid pathology in the brain after ischemia. Folia Neuropathol. 2019, 57, 220-226. [CrossRef]

119. Pluta, R.; Lossinsky, A.S.; Wisniewski, H.M.; Mossakowski, M.J. Early blood-brain barrier changes in the rat following transient complete cerebral ischemia induced by cardiac arrest. Brain Res. 1994, 633, 41-52. [CrossRef]

(C) 2020 by the authors. Licensee MDPI, Basel, Switzerland. This article is an open access article distributed under the terms and conditions of the Creative Commons Attribution (CC BY) license (http://creativecommons.org/licenses/by/4.0/). 